\title{
Intraspecific diversity of Brevibacterium linens, Corynebacterium glutamicum and Rhodococcus erythropolis based on partial 16S rDNA sequence analysis and Fourier-transform infrared (FT-IR) spectroscopy
}

\author{
Helene Oberreuter, Joachim Charzinski and Siegfried Scherer
}

\begin{abstract}
Author for correspondence: Siegfried Scherer. Tel: +49 8161 713516. Fax: +498161714512. e-mail: siegfried.scherer@1rz.tum.de
\end{abstract}

Microbial Ecology Group, Department of Biosciences, Technical University of Munich, Weihenstephaner Berg 3, D-85350 FreisingWeihenstephan, Germany
The intraspecific diversity of 31 strains of Brevibacterium linens, 27 strains of Corynebacterium glutamicum and 29 strains of Rhodococcus erythropolis was determined by partial 165 rDNA sequence analysis and Fourier-transform infrared (FT-IR) spectroscopy. As a prerequisite for the analyses, 27 strains derived from culture collections which had carried invalid or wrong species designations were reclassified in accordance with polyphasic taxonomical data. FT-IR spectroscopy proved to be a rapid and reliable method for screening for similar isolates and for identifying these actinomycetes at the species level. Two main conclusions emerged from the analyses. (1) Comparison of intraspecific 165 rDNA similarities suggested that $R$. erythropolis strains have a very low diversity, B. linens displays high diversity and C. glutamicum occupies an intermediate position. (2) No correlation of FT-IR spectral similarity and 165 rDNA sequence similarity below the species level (i.e. between strains of one species) was observed. Therefore, diversification of $16 \mathrm{~S}$ rDNA sequences and microevolutionary change of the cellular components detected by FT-IR spectroscopy appear to be de-coupled.

Keywords: coryneform bacteria, actinomycetes, $16 \mathrm{~S}$ rDNA sequence analysis, identification, taxonomy

\section{INTRODUCTION}

The assessment of intrataxal variability is an important part of adequate taxon description. The intraspecific diversity of several species has been evaluated by different methods. Several studies have been performed recently employing comparative $16 \mathrm{~S}$ rDNA sequence analysis of complete or partial sequences, but only a limited number of publications deal with a larger number of strains (Ridell et al., 1995; Szállás et al., 1997; Chatellier et al., 1998; Harrington \& On, 1999; Chen et al., 2000). DNA fingerprinting techniques such

Abbreviation: FT-IR, Fourier-transform infrared.

The GenBank accession numbers for the $16 \mathrm{~S}$ rDNA gene sequences reported in this paper are AY017065 to AY017067, AY017069 to AY017087, and AF426135 to AF426143 for Brevibacterium linens; AY017088 to AY017091, AY017093 to AY017104, AY017107 to AY017111, and AF426144 to AF426149 for Corynebacterium glutamicum; and AY017113 to AY017126, AY017128 to AY017138, and AF426150 to AF426153 for Rhodococcus erythropolis. as amplified fragment length polymorphism (Arias et al., 1997; Owen et al., 2001), PFGE (Taylor et al., 1992; Saunders et al., 1997; Sander et al., 1998; Morton et al., 2001), ribotyping (Arias et al., 1997; Zavaleta et al., 1997; Giraffa et al., 2000), random amplified polymorphic DNA fingerprinting (Ridell et al., 1995; Zavaleta et al., 1997; Cibik et al., 2000), multilocus enzyme electrophoresis (Farfán et al., 2000) or PCRDGGE (Dahllöf et al., 2000) and PCR/temperature gradient gel electrophoresis (Nübel et al., 1996), as well as whole-genome DNA-DNA hybridization (Christensen et al., 1997; Szállás et al., 1997; Mehta \& Rosato, 2001), have also been applied, both separately and in combination. A few studies have characterized different strains of Gram-negative species by their LPS or outer-membrane protein profiles (Davies \& Quirie, 1996; Prieto et al., 1999), and some have used a polyphasic approach to qualitatively investigate intraspecific heterogeneity of different species (Arias et al., 1997; Stan-Lotter et al., 1999). 
Knowledge on intraspecific diversity is also important for a correct allocation of isolates to a species contained in any identification database: the more diverse a species is, the more strains must be included in the database in order to represent this species adequately and, consequently, the more reliable is the identification obtained. Fourier-transform infrared (FT-IR) spectroscopy is on its way to becoming a valuable tool for the rapid identification of micro-organisms (e.g. Helm et al., 1991; Curk et al., 1994; Naumann et al., 1994; Holt et al., 1995; Goodacre et al., 1998; Kümmerle et al., 1998). A validated comprehensive FT-IR spectral reference library has been established, by Oberreuter et al. (2002), which allows the rapid identification of coryneform bacteria and related taxa from the two suborders Micrococcineae and Corynebacterineae (Actinomycetales, Actinobacteria) (Stackebrandt et al., 1997).

FT-IR spectroscopy has been used in combination with other techniques for qualitative studies on intraspecific diversity (Seltmann et al., 1994, 1995; Irmscher et al., 1999; Stan-Lotter et al., 1999), but, as far as we are aware, the method has not previously been applied to quantitative assessment of intraspecific diversity, i.e. to quantification of the degree of heterogeneity.

In the present paper, three actinomycete species were chosen which, to our knowledge, have not been previously subjected to any analysis of intraspecific diversity. During the investigation, it became clear that a significant number of strains from official collections were misclassified, in some cases even carrying incorrect genus names. On the basis of polyphasic taxonomical analyses, we propose reclassifications for these strains.

\section{METHODS}

Strains. The strains used for this study are listed in Table 1. Primary depositors and isolation loci are given where available from the official culture collections. A significant proportion of the strains have previously been analysed in terms of physiological properties (Seiler, 1983; Kämpfer et al., 1993) and fatty acid composition (Kämpfer \& Kroppenstedt, 1996). Several strains carry names not included in the Approved Lists of Bacterial Names (Skerman et al., 1980) and which have not been validly published since 1 January 1980 . The strains of $B$. linens were tested for red colony pigmentation upon application of $20 \% \mathrm{KOH}$, a behaviour typical and probably specific for Brevibacterium linens (Grecz \& Dack, 1961; Jones et al., 1973).

FT-IR spectroscopy. Sample preparation was performed according to Kümmerle et al. (1998). The cells were incubated at $30^{\circ} \mathrm{C}$ for $24 \mathrm{~h}$ in tryptone soya agar containing (per l) $15.0 \mathrm{~g}$ tryptone, $5.0 \mathrm{~g}$ soya peptone, $5.0 \mathrm{~g}$ sodium chloride and $15.0 \mathrm{~g}$ agar (Oxoid). All spectra were recorded and evaluated according to Kümmerle et al. (1998), using an IFS-28B FT-IR spectrometer (Bruker). To diminish the difficulties arising from unavoidable baseline shifts and to improve the resolution of complex bands, the first derivation of the digitized original spectra was used. The adjustment of FT-IR parameters, such as selection of spectral frequency ranges, weights and reproducibility levels. was done based on Bruker (1998), but modified (Oberreuter et al., 2002). The spectral distance values obtained by combining the frequency ranges
W1 (3000-2800 $\left.\mathrm{cm}^{-1}\right)$, W2 (1800-1500 $\left.\mathrm{cm}^{-1}\right)$, W3 (1500$\left.1200 \mathrm{~cm}^{-1}\right)$, W4 $\left(1200-900 \mathrm{~cm}^{-1}\right)$ and W5 $\left(900-700 \mathrm{~cm}^{-1}\right)$ were 'normalized' according to the reproducibility of the FT-IR spectra. The software DATAOPUs (Bruker) was used to calculate a matrix listing the spectral distances between the strains of each species in pair-wise comparisons. The spectral distance is a measure of the similarity of the spectra of two strains and corresponds to the size of non-overlapping areas of both spectra.

$16 \mathrm{~S}$ rDNA sequence analysis. After $22 \mathrm{~h}$ growth on tryptone soya agar at $30{ }^{\circ} \mathrm{C}$, the cells of single colonies were lysed and a PCR amplification of the almost complete $16 \mathrm{~S}$ rDNA molecule was performed according to von Stetten et al. (1998). Two universal 16S rDNA binding primers were used for the 30-cycle amplification PCR : 5'f (5'-AGAGTTTGATCCTGGCTCA-3'; position 8-26 in the Escherichia coli numbering system) (Brosius et al., 1978) and 3'r (5'-CGGCTACCTTGTTACGAC-3'; position 1511-1493 in the E. coli numbering system). After PCR amplification, the DNA was purified using the QIAquick PCR purification kit (Qiagen) according to the instructions of the manufacturer, followed by a PEG precipitation of the purified product according to Facius et al. (1999). After purification, the samples were subjected to a cycle-sequencing PCR according to Facius et al. (1999), using the ThermoSequenase fluorescent labelled primer cycle sequencing kit with 7-deaza-dGTP (Amersham Pharmacia Biotech). DMSO (11\%, v/v) and formamide $(7 \%, \mathrm{v} / \mathrm{v})$ were added to facilitate the cycle-sequencing PCR. Fluorescently labelled primers 5'f, 699R [5'-GGGTTG(AGT)GCTCGTT3', E. coli numbering 1114-1100] and/or 927r (5'-CCGCTTGTGCGGGCCC-3', E. coli numbering 942-927) were used for the cycle-sequencing PCR [primer 699R, Ludwig \& Strunk (1999); primer 927r, Amann et al. (1995)] in order to sequence both DNA strands. Considering the addition of formamide, the annealing temperatures for the different cycle sequencing primers used were as follows: $42^{\circ} \mathrm{C}$ for $5^{\prime} \mathrm{f}, 37^{\circ} \mathrm{C}$ for $699 \mathrm{R}$ and $50^{\circ} \mathrm{C}$ for $927 \mathrm{r} ; 25$ cycles were carried out. Sequencing was performed on a LI-COR sequencer (MWG Biotech), typically yielding sequence lengths of approximately $700-900$ bases per run.

The sequences were aligned using the ARB alignment editor (Ludwig \& Strunk, 1999) and trimmed to comprise positions 64-716 in the E. coli numbering system. The ARB software environment was employed to calculate a matrix listing pairwise similarity values between the strains of each species, using a separate consensus filter for each species (Ludwig et al., 1998). Thereby, only those positions at which unambiguous sequence infomation was available for the complete set of reference organisms (600-620 nt) were compared. We restricted our analysis to the highly variable part of the $16 \mathrm{~S}$ rDNA gene in order to increase the resolving power for this molecule.

Identification of the strains for reclassification was accomplished by comparison of the partial sequences with database sequences from ARB, GenBank (Altschul et al., 1997) and the Ribosomal Database Project (Maidak et al., 2000). Identification of a sequence in the ARB software environment was accomplished by addition of the aligned query sequence into a validated and optimized maximum-parsimony tree based on $16 \mathrm{~S}$ rDNA sequences while keeping the tree topology constant (Ludwig et al., 1998).

Statistical evaluation. The matrices listing pair-wise spectral distance or similarity values for all strains of each species contain $n \pm(n-1) / 2$ elements, where $n$ is the number of strains, i.e. 351 values for 27 strains of Corynebacterium glutamicum, 406 values for 29 strains of Rhodococcus 
Table 1. Strains analysed

\begin{tabular}{|c|c|c|c|c|c|c|}
\hline \multirow[t]{2}{*}{$\begin{array}{l}\text { WS } \\
\text { no.* }\end{array}$} & \multirow[t]{2}{*}{$\begin{array}{c}\text { Original strain } \\
\text { designation } \dagger\end{array}$} & \multirow[t]{2}{*}{$\begin{array}{l}\text { Initial depositor or } \\
\text { source } \neq\end{array}$} & \multirow[t]{2}{*}{$\begin{array}{l}\text { Source of } \\
\text { isolation } \neq\end{array}$} & \multicolumn{3}{|c|}{$\begin{array}{c}\text { Clusters of } \\
\text { numerical studies } \$\end{array}$} \\
\hline & & & & A & B & $\mathrm{C}$ \\
\hline & Corynebacterium glutamicum & & & & & \\
\hline 1084 & ATCC 14017 ('Brevibacterium chang-fua') & Wei-chuan Foods Corp. & Rice-puddle soil, Formosa & E I & 47 & $\mathrm{I}-1$ \\
\hline 1086 & $\begin{array}{l}\text { ATCC } 13747 \text { ('Brevibacterium } \\
\text { glutamigenes') }\end{array}$ & Wei-chuan Foods Corp. & Soil & E I & & \\
\hline 1096 & $\begin{array}{l}\text { ATCC } 14066 \text { ('Brevibacterium } \\
\text { saccharolyticum') }\end{array}$ & Ajinomoto Co., Inc. & & E I & 12 & \\
\hline 1097 & ATCC 14915 ('Brevibacterium seonmiso') & Shinhan Flour Mill Co. & & E I & 47 & $\mathrm{I}-1$ \\
\hline 1100 & ATCC 19165 (Brevibacterium sp.) & T. T. Cheng & Uncultivated soil & E I & & \\
\hline 1103 & ATCC 13744 ('Brevibacterium taipei’) & Wei-chuan Foods Corp. & Soil & E I & 47 & $\mathrm{I}-1$ \\
\hline 1104 & $\begin{array}{l}\text { ATCC } 19240 \text { ('Brevibacterium } \\
\text { thiogenitalis') }\end{array}$ & Takeda Chem Ind. & Soil & E I & 47 & $\mathrm{I}-1$ \\
\hline 1105 & ATCC 15283 (Microbacterium sp.) & Won Hyung Ind. Company & Soil & E I & & \\
\hline 1493 & ATCC 13059 & Kyowa Ferm. Ind. Co. & Derived from ATCC $13032^{\mathrm{T}}$ & E I & 47 & $\mathrm{I}-1$ \\
\hline 1494 & ATCC 13060 & Kyowa Ferm. Ind. Co. & Derived from ATCC $13032^{\mathrm{T}}$ & E I & 47 & $\mathrm{I}-1$ \\
\hline 1495 & ATCC 13232 & Kyowa Ferm. Ind. Co. & & E I & 47 & $\mathrm{I}-1$ \\
\hline 1496 & ATCC 13286 & Kyowa Ferm. Ind. Co. & Derived from ATCC $13032^{\mathrm{T}}$ & E I & 47 & \\
\hline 1497 & ATCC 13287 & Kyowa Ferm. Ind. Co. & Derived from ATCC $13032^{\mathrm{T}}$ & E I & 47 & $\mathrm{I}-1$ \\
\hline 1499 & ATCC 15025 & Kyowa Ferm. Ind. Co. & & E I & 47 & $\mathrm{I}-1$ \\
\hline 1572 & ATCC 13746 & Wei-chuan Foods Corp. & Soil & E I & 47 & \\
\hline 1575 & ATCC 21517 & Kyowa Ferm. Ind. Co. & & E I & 47 & $\mathrm{I}-1$ \\
\hline 1582 & ATCC 21179 & Kyowa Ferm. Ind. Co. & & E I & 47 & \\
\hline 1605 & NCIB 9666 (Arthrobacter sp.) & H. L. Kornberg & Soil & E I & 47 & \\
\hline 1727 & ATCC 14399 ('Micrococcus maripuniceus') & C. E. Zobell & Marine & E I & & \\
\hline 1756 & DSM 20163 & Wei-chuan Food Corp. & Soil & E I & & \\
\hline 1757 & ATCC 14067 & Ajinomoto Co., Inc. & & E I & 47 & $\mathrm{I}-1$ \\
\hline 1795 & DSM 20137 & $\begin{array}{l}\text { Int Mineral and Chemical } \\
\text { Corp. }\end{array}$ & & E I & 47 & $\mathrm{I}-1$ \\
\hline 1863 & & W. Hennlich & Liquid pig manure & & 47 & $\mathrm{I}-1$ \\
\hline 1912 & & H. Seiler & & & 47 & $\mathrm{I}-1$ \\
\hline 1940 & ATCC 13655 & Ajinomoto Co., Inc. & & E I & 12 & \\
\hline 2041 & ATCC 21492 & Ajinomoto Co., Inc. & $\begin{array}{l}\text { Mutant derived from ATCC } \\
13032^{\mathrm{T}}\end{array}$ & E I & 47 & $\mathrm{I}-1$ \\
\hline 2049 & DSM $20300^{\mathrm{T}}$ & Kyowa Ferm. Ind. Co. & Sewage & E I & 47 & $\mathrm{I}-1$ \\
\hline & Rhodococcus erythropolis & & & & & \\
\hline 1075 & ATCC 21788 ('Arthrobacter oxamicetus') & Bristol Labs & Soil, Chiba, Japan & A II & 100 & $\mathrm{I}-4$ \\
\hline 1076 & $\begin{array}{l}\text { ATCC } 21814 \text { ('Arthrobacter oxamicetus } \\
\text { subsp. propiophenicolus') }\end{array}$ & Bristol Labs & Soil, Japan & A II & & \\
\hline 1077 & ATCC 15590 ('Arthrobacter paraffineus') & Kyowa Ferm. Ind. Co. & Soil & A II & 100 & $\mathrm{I}-4$ \\
\hline 1079 & DSM 20665 & R. L. Tate & Soil & & 100 & $\mathrm{I}-4$ \\
\hline 1088 & ATCC 15527 ('Brevibacterium healii’) & $\begin{array}{l}\text { Esso Research \& } \\
\text { Engineering Co. }\end{array}$ & Soil & A II & 100 & $\mathrm{I}-4$ \\
\hline 1094 & $\begin{array}{l}\text { ATCC } 21195 \text { ('Brevibacterium } \\
\text { paraffinoliticum’) }\end{array}$ & Kyowa Ferm. Ind. Co. & Soil & & 101 & \\
\hline $1114 \_1$ & ATCC 21194 ('Corynebacterium alkanum') & Kyowa Ferm. Ind. Co. & Soil & A rest & 103 & \\
\hline 1115 & $\begin{array}{l}\text { ATCC } 21362 \text { ('Corynebacterium } \\
\text { aurantiacum') }\end{array}$ & Kyowa Ferm. Ind. Co. & & A II & 100 & $\mathrm{I}-4$ \\
\hline 1119 & $\begin{array}{l}\text { ATCC } 21108 \text { ('Corynebacterium } \\
\text { humiferum') }\end{array}$ & Takeda Chem Ind. & & A II & 100 & $\mathrm{I}-4$ \\
\hline 1120 & ATCC 15961 (Rhodococcus sp.) & Ajinomoto Co., Inc. & Soil & A II & 100 & \\
\hline 1121_1 & ATCC 15108 (Rhodococcus sp.) & Ajinomoto Co., Inc. & & A II & 102 & \\
\hline
\end{tabular}


Table 1 (cont.)

\begin{tabular}{|c|c|c|c|c|c|c|}
\hline \multirow[t]{2}{*}{$\begin{array}{l}\text { WS } \\
\text { no.* }\end{array}$} & \multirow[t]{2}{*}{$\begin{array}{c}\text { Original strain } \\
\text { designation } \dagger\end{array}$} & \multirow[t]{2}{*}{$\begin{array}{l}\text { Initial depositor or } \\
\text { source } \neq\end{array}$} & \multirow[t]{2}{*}{$\begin{array}{l}\text { Source of } \\
\text { isolation } \neq\end{array}$} & \multicolumn{3}{|c|}{$\begin{array}{c}\text { Clusters of } \\
\text { numerical studies } \$\end{array}$} \\
\hline & & & & A & B & $\mathrm{C}$ \\
\hline 1440 & DSM 312 & K. Taraka \& K. Kimura & Soil & A II & 100 & $\mathrm{I}-4$ \\
\hline 1458 & $\begin{array}{c}\text { ATCC } 21190 \text { ('Arthrobacter } \\
\text { bydrocarboglutamicus') }\end{array}$ & Kyowa Ferm. Ind. Co. & & & 100 & $\mathrm{I}-4$ \\
\hline 1510 & exDSM 43065 & & & A II & & \\
\hline 1518 & DSM $43066^{\mathrm{T}}$ & P. H. Gray & Soil & A II & & \\
\hline 1583 & ATCC 21035 (Rhodococcus sp.) & Takeda Chem Ind. & Soil & A II & & \\
\hline 1603 & $\begin{array}{l}\text { ATCC } 21222 \text { ('Brevibacterium } \\
\text { ketoglutamicum') }\end{array}$ & Kyowa Ferm. Ind. Co. & & A II & 100 & $\mathrm{I}-4$ \\
\hline 1800 & ATCC 19369 & M. Brown & Chalk soil & & & \\
\hline 1804 & DSM 43060 & K. A. Bissett & Soil & & & \\
\hline $1944 \_2$ & DSM 313 & Ayerst Lab., Inc. & & & 100 & \\
\hline 2036 & IAM 1474 & H. Iizuka \& K. Komagata & Soil in petroleum zone & A II & & \\
\hline 2071 & Splitstoesser 66 (VI) (Corynebacterium sp.) & D. F. Splitstoesser & & A II & 100 & $\mathrm{I}-4$ \\
\hline 2072 & Splitstoesser 60 (VI) (Corynebacterium sp.) & D. F. Splitstoesser & & A II & 100 & $\mathrm{I}-4$ \\
\hline 2079 & NCIB 9646 (Rhodococcus sp.) & T. Gibson & & A II & 100 & $\mathrm{I}-4$ \\
\hline 2096 & DSM 311 & K. Tanaka & Soil & A II & 100 & \\
\hline 2126 & IAM 1399 & H. Iizuka \& K. Komagata & Soil in petroleum zone & A II & 100 & \\
\hline 3526 & & K. Gutser & Milk & & & \\
\hline 3527 & & K. Gutser & Milk & & & \\
\hline \multirow[t]{2}{*}{3528} & & K. Gutser & Milk & & & \\
\hline & Brevibacterium linens & & & & & \\
\hline 1504 & AC 474 (Corynebacterium sp.) & $\begin{array}{l}\text { I. Antheunisse \& W. H. } \\
\text { Crombach }\end{array}$ & & C VII & 90 & II-11 \\
\hline 1694 & ATCC 9174 & H. Weigmann & $\begin{array}{l}\text { Romadur cheese, Kiel, } \\
\text { Germany }\end{array}$ & & & \\
\hline 1778 & DSM 20426 & Yale & Camembert cheese & & 90 & \\
\hline 1782 & DSM $20425^{\mathrm{T}}$ & H. Weigmann & Harzer cheese & & 90 & \\
\hline 1917 & Seiler 195 & H. Seiler & & & 90 & II-11 \\
\hline 1939 & AC 825 & $\begin{array}{l}\text { I. Antheunisse \& W. H. } \\
\text { Crombach }\end{array}$ & & C VII & 90 & II-11 \\
\hline 1949 & AC 252 & $\begin{array}{l}\text { I. Antheunisse \& W. H. } \\
\text { Crombach }\end{array}$ & & C VII & 90 & II-11 \\
\hline 1950 & AC 478 & $\begin{array}{l}\text { I. Antheunisse \& W. H. } \\
\text { Crombach }\end{array}$ & & C VII & 90 & \\
\hline 1951 & AC 251 & $\begin{array}{l}\text { I. Antheunisse \& W. H. } \\
\text { Crombach }\end{array}$ & & C VII & & \\
\hline 1952 & AC 578 & $\begin{array}{l}\text { I. Antheunisse \& W. H. } \\
\text { Crombach }\end{array}$ & & C VII & 90 & \\
\hline 1968 & NCDO 1002 & P. Kastli & & C VII & 90 & II-11 \\
\hline 1975 & AC 831 & $\begin{array}{l}\text { I. Antheunisse \& W. H. } \\
\text { Crombach }\end{array}$ & & C VII & 90 & \\
\hline 2801 & & M. Carnio & Semi-hard cheese & & & \\
\hline 2888 & & I. Eppert & & & & \\
\hline 2890 & M18 & N. Valdés-Stauber & Red smear cheese & & & \\
\hline 2903 & & Starter-culture company F & & & & \\
\hline 2904 & & Starter-culture company F & & & & \\
\hline 2906 & & Starter-culture company N & & & & \\
\hline 2909 & & Starter-culture company E & & & & \\
\hline 2910 & & Starter-culture company E & & & & \\
\hline 2911 & & Dairy K & German soft cheese & & & \\
\hline
\end{tabular}


Table 1 (cont.)

\begin{tabular}{|c|c|c|c|c|c|c|}
\hline \multirow[t]{2}{*}{$\begin{array}{l}\text { WS } \\
\text { no.* }\end{array}$} & \multirow[t]{2}{*}{$\begin{array}{c}\text { Original strain } \\
\text { designation } \dagger\end{array}$} & \multirow[t]{2}{*}{$\begin{array}{c}\text { Initial depositor or } \\
\text { source } \neq\end{array}$} & \multirow[t]{2}{*}{$\begin{array}{l}\text { Source of } \\
\text { isolation } \neq\end{array}$} & \multicolumn{3}{|c|}{$\begin{array}{c}\text { Clusters of } \\
\text { numerical studies } \$\end{array}$} \\
\hline & & & & A & B & $\mathrm{C}$ \\
\hline 3030 & & Starter-culture company N & & & & \\
\hline 3033 & & Starter-culture company N & & & & \\
\hline 3037 & & Starter-culture company F & & & & \\
\hline 3038 & & Starter-culture company F & & & & \\
\hline 3211 & & N. Valdès-Stauber & & & & \\
\hline 3215 & & N. Valdès-Stauber & & & & \\
\hline 3459 & & M. Carnio & French raclette cheese & & & \\
\hline 3460 & & M. Carnio & French raclette cheese & & & \\
\hline 3541 & & Dairy V & Danish tilsit cheese & & & \\
\hline 3542 & & Dairy V & Danish tilsit cheese & & & \\
\hline
\end{tabular}

*WC, Weihenstephan Culture Collection, Institute of Microbiology, FML Weihenstephan, Freising, Germany.

† Binomials in single quotes are not in the approved lists of bacterial names (Skerman et al., 1980) and have not been validly published since 1 January $1980 .^{T}$, type strain. Abbreviations of original strain designations: AC, I. Antheunisse and W. H. Crombach, University of Wageningen, The Netherlands; ATCC, American Type Culture Collection, Manassas, VA, USA; DSM, Deutsche Sammlung von Mikroorganismen und Zellkulturen, Braunschweig, Germany; IAM, Institute of Applied Microbiology, Tokyo, Japan; NCDO, National Collection of Dairy Organisms, Reading, UK; NCIB, National Collection of Industrial Bacteria, Aberdeen, UK; Splitstoesser, O. F., Cornell University, NY, USA.

$\ddagger$ The initial depositor/source and source of isolation are according to the official collections or our own data. Starter-culture companies and dairies are indicated by single letters.

\$Numerical studies under comparison: A, Seiler (1983); B, Kämpfer et al. (1993); C, Kämpfer \& Kroppenstedt (1996). Cluster designations are taken from the respective publications.

erythropolis, and 465 values for 31 strains of $B$. linens. Spectral distance and $16 \mathrm{~S}$ rDNA similarity distributions (histograms) were created by a computer program which grouped the matrix values into classes and determined the relative frequency of occurrence in each class. Class widths of 0.25 distance units for spectral distances and 0.5 percentage points for $16 \mathrm{~S}$ rDNA similarity values were chosen for visualization. Distance or similarity values coinciding with a class boundary were counted in the lower of the two possible classes. The frequency values were normalized to make the sum of all relative frequency values $100 \%$ and were plotted as histograms versus the corresponding class intervals. Distance versus similarity correlation graphs were created by plotting the pair-wise spectral distance versus the corresponding $16 \mathrm{~S}$ rDNA sequence similarity for each combination of strains.

\section{RESULTS AND DISCUSSION}

\section{FT-IR spectroscopy is a reliable and rapid method for screening and species identification}

To assess intraspecific variability, the classification of all strains under investigation at the species level must be unequivocal. Table 1 lists the strains used for this study. A significant proportion of the strains have previously been analysed according to their physiological properties (Seiler, 1983; Kämpfer et al., 1993) and fatty acid composition (Kämpfer \& Kroppenstedt, 1996). Cluster designations of these analyses are given in the cases where the particular strains were included in the respective study.
All 25 strains of C. glutamicum, including the strains which carry invalid species names given in single quotes, are grouped into the same cluster ('E I') in the numerical analysis by Seiler (1983). Most of these strains were also analysed by Kämpfer et al. (1993) and Kämpfer \& Kroppenstedt (1996). In the latter two publications, all of them are located in the same respective clusters of ' $C$. glutamicum' except for strains ATCC 13655 and 14066, which were grouped differently into a small 'Brevibacterium'/Corynebacterium cluster (Kämpfer et al., 1993), in which, however, a strain denoted as C. glutamicum was also included. An FT-IR cluster analysis (Fig. 1) depicting the spectral similarities between these strains as well as type strains from other Corynebacterium spp. clearly shows that all of these strains exhibit a relatively high level of spectral similarity. They are clearly separated from the type strains of other Corynebacterium species. Comparative $16 \mathrm{~S}$ rDNA sequence analysis of the partial sequences with the programs RDP, ARB and GenBank's BLAST resulted in an overall allocation to the species C. glutamicum in all cases. The minimal similarity between the partial sequences of all strains and the type strain's sequence was $97.5 \%$. On the basis of this polyphasic approach, we propose reclassification of the strains ATCC 13744, ATCC 13747, ATCC 14017, ATCC 14066, ATCC 14399, ATCC 14915, ATCC 15283, ATCC 19165, ATCC 19240 and NCIB 9666 (Table 1) as Corynebacterium glutamicum. 


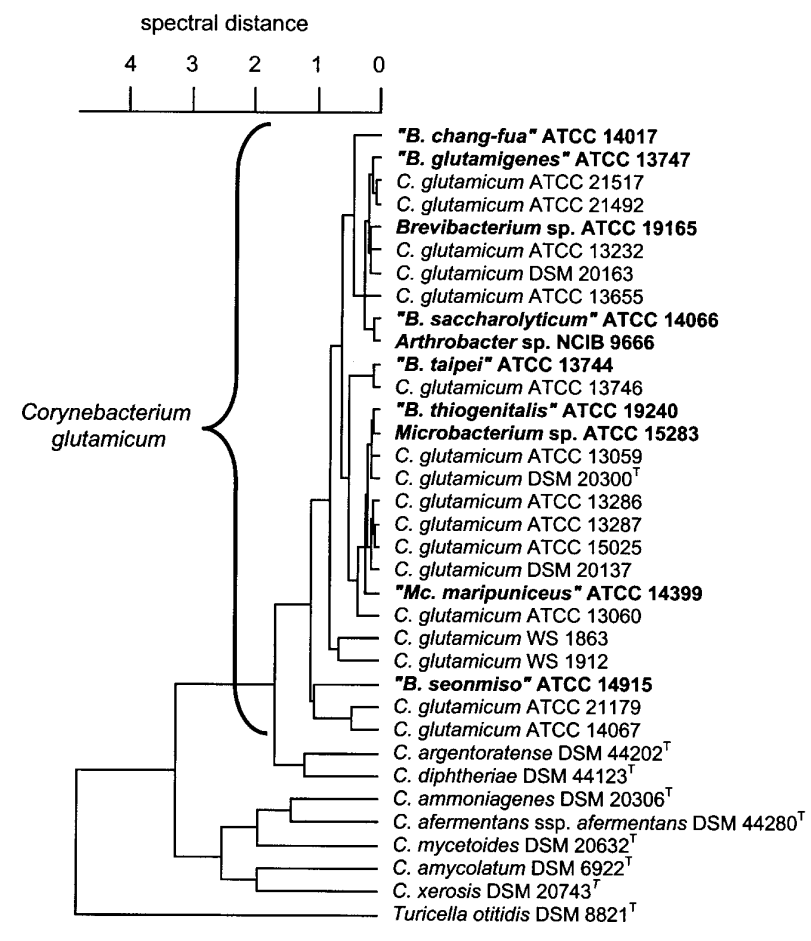

Fig. 1. IR spectral dendrogram of 27 strains of C. glutamicum and the type strains of other Corynebacterium spp. and Turicella otitidis. Abbreviations: B, Brevibacterium; C, Corynebacterium; M., Micrococcus. Quotation marks indicate invalid species names. Strains within the C. glutamicum cluster not designated by this name are proposed for reclassification (in bold). Mean linkage, spectral distance normalized to reproducibility level. Frequency ranges with weights and reproducibility levels: $3000-2800 \mathrm{~cm}^{-1} / 0 \cdot 8 / 3 \cdot 3 ; \quad 1800-1500 \mathrm{~cm}^{-1} / 0 \cdot 8 / 5$; $1500-$ $1200 \mathrm{~cm}^{-1} / 0 \cdot 9 / 20 ; 1200-900 \mathrm{~cm}^{-1} / 0 \cdot 9 / 33 ; 900-700 \mathrm{~cm}^{-1} / 0 \cdot 9 / 116$. The unweighted pair group method algorithm (UPGMA) was used.

Likewise, the majority of the R. erythropolis strains has been subjected to the same numerical taxonomic analyses. All strains investigated by Kämpfer \& Kroppenstedt (1996) fell into the same cluster, 'I-4', designated as 'Corynebacterium sp.'. Seiler (1983) grouped all strains into the same cluster, 'A II', except for ATCC 21194, which was separated only by a small distance. Within a phenogram, all strains form a distinct sub-branch (Kämpfer et al., 1993). Again, FT-IR spectroscopy showed a very high spectral similarity between these 26 strains (data not shown), and $16 \mathrm{~S}$ rDNA sequence analysis revealed a strong similarity to R. erythropolis. We therefore propose reclassification of the strains ATCC 15108, ATCC 15527, ATCC 15590, ATCC 15961, ATCC 21035, ATCC 21108, ATCC 21190, ATCC 21194, ATCC 21195, ATCC 21222, ATCC 21362, ATCC 21788, ATCC 21814, NCIB 9646, WS 2071 [Splitstoesser 66 (VI)] and WS 2072 [Splitstoesser 60 (VI)] (Table 1) as R. erythropolis.

All 23 strains of $B$. linens displayed an orange colony colour after $2 \mathrm{~d}$ incubation in light on tryptone soya agar. A drop of $20 \% \mathrm{KOH}$ resulted in red colony pigmentation, a behaviour typical of, and probably specific to, B. linens (Grecz \& Dack, 1961; Jones et al., 1973). The strains which have been investigated by Seiler (1983), Kämpfer et al. (1993) and Kämpfer \& Kroppenstedt (1996) were part of the same cluster in each case. The partial $16 \mathrm{~S}$ rDNA sequences of all strains showed a level of similarity of at least $96.7 \%$ to the sequence of the type strain. In the cases of WS 2903, WS 2906 and WS 3459, sequence similarities to the closely related type strains of Brevibacterium casei or Brevibacterium iodinum were noted. However, since these two species are characterized by different colony morphology and pigmentation, the strains may be considered strains of the species $B$. linens. Therefore, we propose reclassification of AC 474 (Table 1) as B. linens.

According to Stackebrandt \& Goebel (1994), a $16 \mathrm{~S}$ rDNA similarity of more than $97 \%$ for complete sequences strongly points to species identity between the queried sequence and the type-strain sequence, although there are exceptions to this rule (e.g. Fox et al., 1992; Lechner et al., 1998). Some pair-wise similarity values are somewhat lower than the 'cut-off value' of $97 \%$ sequence similarity, but we decided not to question species identity in these cases. Considering, in addition, that major sequence variations occur in the first part of the sequence (Chatellier et al., 1998; Ludwig et al., 1998), the complete sequences show greater percentage similarity to the sequence of the type strain than do the partial sequences. Moreover, it has been recommended that the threshold value be lowered in order to maintain flexibility in the phylogenetic definition of a species (Stackebrandt \& Goebel, 1994; Rosselló-Mora \& Amann, 2001).

Based on this approach as well as the polyphasic taxonomic data reported in the literature, we conclude that all strains included in this analysis indeed belong to one of the three species under investigation. This result is a prerequisite for assessing intraspecific variability, which is the main topic of this publication and is reported in the following section. Concerning species identification, it is important to note that for 86 out of 87 strains investigated, FT-IR spectroscopic analysis arrived at the same result as $16 \mathrm{~S}$ rDNA sequence analysis. The only exception was B. linens WS 3541, whose IR spectrum was misidentified as that of Demetria terragena at the first hit while all other hits of the identification hit list consisted of $B$. linens strains. This demonstrates that FT-IR spectroscopy is a fast and reliable screening method for identifying unknown actinomycetes at the species level (compare Tindall et al., 2000). However, as has been stated previously, this method cannot be used for classification (Kümmerle et al., 1998; Oberreuter et al., 2002).

\section{Intraspecific variability of different species}

Reliable assessment of intraspecific variability depends on correct strain allocation to a particular species (see above). Furthermore, it is only possible if the strains under investigation are of independent origin. Table 1 lists the original depositor or source together with the 


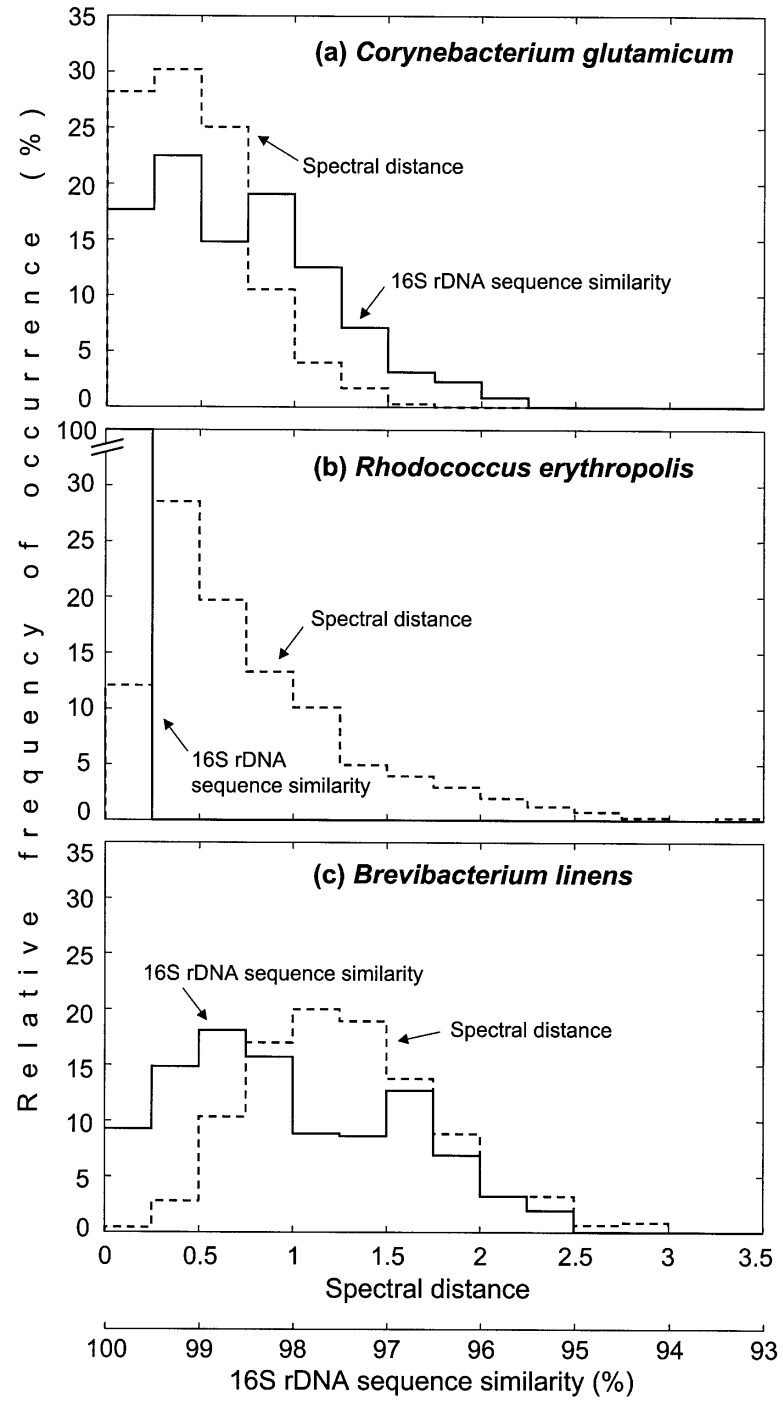

Fig. 2. Distribution histograms of pair-wise partial $16 \mathrm{~S}$ rDNA sequence similarity values and IR spectral distance values: the relative frequency of occurrence in each class is plotted against the corresponding class intervals.

isolation locus for each strain, as far as could be determined from the information available in the official collections. These data are not always precise enough to derive firm conclusions as to strain origins. It is probable, however, that most of the strains from $C$. glutamicum and R. erythropolis were isolated from East-Asian environmental sources, and that the B. linens strains came from Middle-European sources. We also assume that the majority of these strains represent different isolates, except for the five C. glutamicum strains ATCC 13059, ATCC 13060, ATCC 13286, ATCC 13287 and ATCC 21492, which appear to be mutants of the type strain (Table 1).

The 27 strains of C. glutamicum exhibited a comparatively high degree of spectral similarity (Fig. 2a). The distribution of pair-wise FT-IR spectral distance values ranged from 0.07 to 1.51 (mean at 0.48 ), focusing around 0.3 and then declining relatively steeply towards higher spectral distance values. On the other hand, the degree of $16 \mathrm{~S}$ rDNA sequence similarity between the strains of C. glutamicum was lower. The distribution of the pair-wise sequence similarity values ranged from 95.7 to $100 \%$ (mean at $98.5 \%$ ). This means that even though each of the strains showed a sequence similarity of at least $97.5 \%$ to the type-strain sequence, pair-wise sequence comparison between the individual strains revealed similarities as low as $95 \cdot 7 \%$.

The 29 strains of R. erythropolis displayed an extremely high level of $16 \mathrm{~S}$ rDNA sequence similarity (between 99.8 and $100 \%$, with a mean at $99 \cdot 9 \%$ ). For this reason, all strains of $R$. erythropolis were grouped into the same class in Fig. 2(b). However, in sharp contrast, the variability between their FT-IR spectra was rather high. The distribution of spectral distance values ranged from 0.03 to 3.26 (mean at 0.77 ), focusing at a value around 0.3 and gradually declining towards larger distance values. This result is in favour of an independent origin for these isolates, in spite of the high similarity of the $16 \mathrm{~S}$ rDNA sequences.

The highest intraspecific diversity was noted for $B$. linens. Spectral distance values between the 31 strains analysed ranged from 0.19 to 2.94 with a mean value of $1 \cdot 3$ (Fig. 2c). The distance distribution closely resembles a Gaussian bell curve around the mean. For this species, a comparatively wide distribution of spectral distance values between the different strains was observed. The distribution of pair-wise $16 \mathrm{~S}$ rDNA similarity values is likewise spread out rather far between 95.3 to $100 \%$, with a maximum between 98.5 and $99.0 \%$ (mean at $98.0 \%)$. Much as for C. glutamicum, $16 \mathrm{~S}$ rDNA sequence similarities as low as $95.3 \%$ were noted between different strains in pair-wise comparisons, although each of the strains showed a minimal sequence similarity of $96.6 \%$ to the type strain sequence.

Several publications report on the use of comparative $16 \mathrm{~S}$ rDNA sequence analysis for assessment of intraspecific variability, but in-depth studies dealing with larger numbers of strains are comparatively rare. Sixteen strains of Xylella fastidiosa exhibited a $16 \mathrm{~S}$ rDNA sequence similarity of $99 \cdot 0-100 \%$ over the complete sequence (Chen et al., 2000), much like R. erythropolis. Campylobacter byointestinalis (Harrington \& On, 1999) and Streptococcus suis (Chatellier et al., 1998) displayed a high levels of interstrain sequence variability $(95 \cdot 7-100 \%$ and $93 \cdot 9-100 \%$ over the complete sequence, respectively) similar to those for $C$. glutamicum and especially $B$. linens. It appears to be a significant result of our study that the intraspecific heterogeneity of these three bacterial species is quite different. When a high variability is found within the members of a species, such species are termed polytypic when distinct subspecies can be defined. When no clear subspecies occur, the term polymorphic is more appropriate (Mallet, 2001). B. linens appears to be a polymorphic species, according to both $16 \mathrm{~S} \mathrm{rDNA}$ and FT-IR spectroscopic variability. However, this conclusion needs to be supported by sequencing of other 


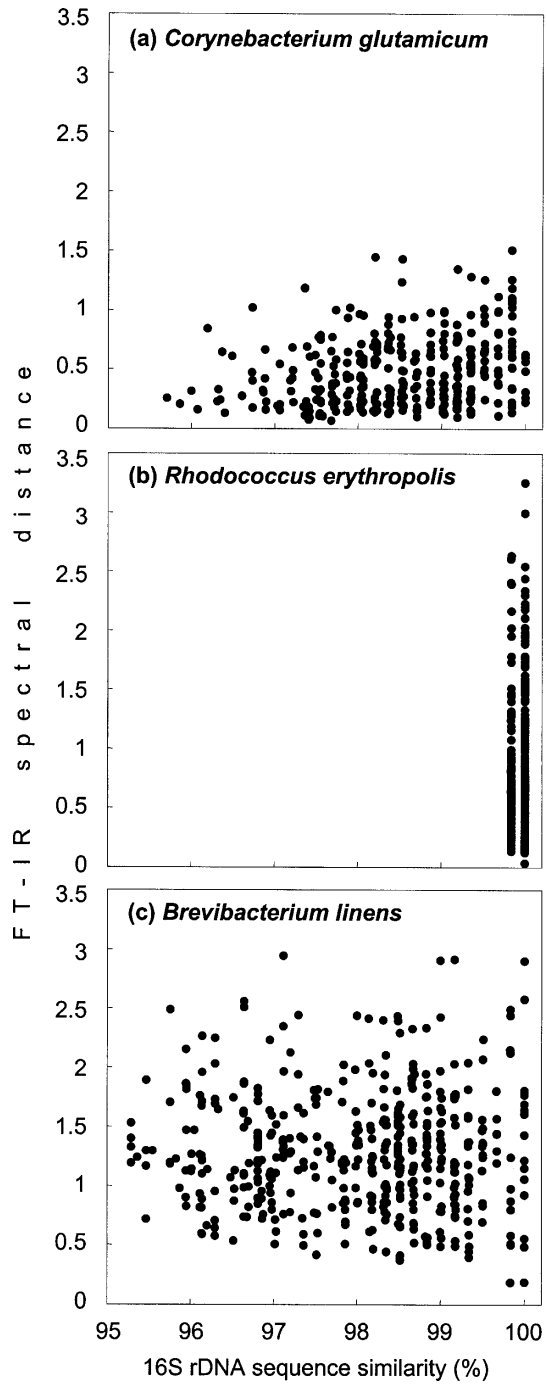

Fig. 3. Correlation graphs of pair-wise IR spectral distance values plotted against corresponding $16 \mathrm{~S}$ rDNA sequence similarity values. (a) C. glutamicum: 351 value pairs. (b) $R$. erythropolis: 406 value pairs. (c) B. linens: 465 value pairs.

loci as well. Only such analyses will show whether $16 \mathrm{~S}$ rDNA or FT-IR data are suitable markers for a polymorphic species structure. Generally, comparative analyses of the heterogeneity within bacterial species are still at an early stage (compare Rosselló-Mora \& Amann, 2001).

\section{FT-IR spectral similarity and 16S rDNA similarity are not correlated}

FT-IR spectroscopy as a physico-chemical, whole-cell fingerprint technique analyses microbial cells on a completely different basis from techniques focusing on a small conserved region of the genome such as the $16 \mathrm{~S}$ rDNA gene. We wanted to determine if FT-IR spectroscopy reflects the diversity obtained by sequence comparison, at least to some degree; in other words, whether a correlation exists between the pair-wise IR spectral distance values and the pair-wise $16 \mathrm{~S}$ rDNA similarity values. For this purpose, spectral distances were plotted against their corresponding 16S rDNA similarity values for each pair of strains (Fig. 3). This analysis shows that within C. glutamicum and B. linens (Fig. 3a, c) there are strain pairs which are spectrally very close but have a low $16 \mathrm{~S}$ rDNA similarity (bottom left of each plot). Others display a highly similar $16 \mathrm{~S}$ rDNA but have very different IR absorption spectra (top right of each plot). In the former cases, the $16 \mathrm{~S}$ rDNA sequence analysis has a better resolution than FT-IR spectroscopy, whereas in the latter cases, different strains which cannot be distinguished by partial $16 \mathrm{~S}$ rDNA analysis can be distinguished via FT-IR spectroscopy. The strains of R. erythropolis (Fig. 3b) differed at only two nucleic acid positions, and therefore the entire observed spectral variability is plotted against sequence similarities of 99.9 and 100 percentage points. However, a considerable number of strain pairs can be distinguished by FT-IR spectroscopy.

No correlation was found between $16 \mathrm{~S}$ rDNA sequence similarity and FT-IR spectral distance for the three species under investigation. We conclude that diversification of $16 \mathrm{~S}$ rDNA sequences and the microevolutionary change of the cellular overall characters measured by FT-IR spectroscopy appear not to be coupled. Since $16 \mathrm{~S}$ rDNA sequence comparison is considered to be the current 'gold standard' for elucidating bacterial phylogeny (Amann et al., 1994; Ludwig et al., 1998; Ludwig \& Schleifer, 1999), FT-IR spectroscopy cannot be used to assess the evolutionary relationships of strains within these actinomycete species. It has been demonstrated previously that FT-IR spectroscopy is not a reliable parameter for establishing taxonomic relationships between different genera of yeasts (Kümmerle et al., 1998).

\section{ACKNOWLEDGEMENTS}

The authors wish to thank Wolfgang Ludwig for providing the ARB software environment and the ARB 16S rDNA database, and for providing valuable information and help whenever necessary. Thanks are due to Michael Kümmerle and Felix von Stetten for introducing H.O. to FT-IR spectroscopy and molecular microbiology, respectively. We are grateful to several starter-culture companies for supplying us with strains. The technical assistance of Sven Illgner, Patrizia Hägele and Louise Arnold is greatly appreciated. Cornelia Fischer is acknowledged for excellent technical assistance. This work was supported by the FEI (Forschungskreis der Ernährungsindustrie e.V., Bonn), the AiF (Arbeitskreis für industrielle Forschung) and the Ministry of Economics and Technology (project no. $11627 \mathrm{~N}$ ).

\section{REFERENCES}

Altschul, S. F., Madden, T. L., Schäffer, A. A., Zhang, J., Zhang, Z., Miller, W. \& Lipman, D. J. (1997). Gapped BLAST and PSI-BLAST: a new generation of protein database search programs. Nucleic Acids Res 25, 3389-3402.

Amann, R., Ludwig, W. \& Schleifer, K.-H. (1994). Identification of uncultured bacteria: a challenging task for molecular taxonomists. ASM News 60, 360-365. 
Amann, R., Ludwig, W. \& Schleifer, K.-H. (1995). Phylogenetic identification and in situ detection of individual microbial cells without cultivation. Microbiol Rev 59, 143-169.

Arias, C. R., Verdonck, L., Swings, J., Aznar, R. \& Garay, E. (1997). A polyphasic approach to study the intraspecific diversity amongst Vibrio vulnificus isolates. Syst Appl Microbiol 20, 622-633.

Brosius, J., Palmer, M. L., Kennedy, P. J. \& Noller, H. F. (1978). Complete nucleotide sequence of a $16 \mathrm{~S}$ ribosomal RNA gene from Escherichia coli. Proc Natl Acad Sci U S A 75, 4801-4805.

Bruker (1998). Charakterisierung von Mikroorganismen mit der FT-IR Spektroskopie - Arbeitsanleitung zum IFS 28/B, Version 3.0. Germany: Bruker.

Chatellier, S., Harel, J., Zhang, Y., Gottschalk, M., Higgins, R., Devriese, L. A. \& Brousseau, R. (1998). Phylogenetic diversity of Streptococcus suis strains of various serotypes as revealed by $16 \mathrm{~S}$ rRNA gene sequence comparison. Int J Syst Bacteriol 48, 581-589.

Chen, J., Jarret, R. L., Qin, X., Hartung, J. S., Banks, D., Chang, C. J. \& Hopkins, D. L. (2000). $16 \mathrm{~S}$ rDNA sequence analysis of Xylella fastidiosa strains. Syst Appl Microbiol 23, 349-354.

Christensen, J. J., Whitney, A. M., Teixeira, L. M., Steigerwalt, A. G., Facklam, R. R., Korner, B. \& Brenner, D. J. (1997). Aerococcus urinae: intraspecies genetic and phenotypic relatedness. Int J Syst Bacteriol 47, 28-32.

Cibik, R., Lepage, E. \& Tailliez, P. (2000). Molecular diversity of Leuconostoc mesenteroides and Leuconostoc citreum isolated from traditional French cheeses as revealed by RAPD fingerprinting, $16 \mathrm{~S}$ rDNA sequencing and $16 \mathrm{~S}$ rDNA fragment amplification. Syst Appl Microbiol 23, 267-278.

Curk, M. C., Peladan, F. \& Hubert, J. C. (1994). Fourier transform infrared (FTIR) spectroscopy for identifying Lactobacillus species. FEMS Microbiol Lett 123, 241-248.

Dahllöf, I., Baillie, H. \& Kjelleberg, S. (2000). rpoB-based microbial community analysis avoids limitations inherent in $16 \mathrm{~S}$ rRNA gene intraspecies heterogeneity. Appl Environ Microbiol 66, 3376-3380.

Davies, R. L. \& Quirie, M. (1996). Intra-specific diversity within Pasteurella trehalosi based on variation of capsular polysaccharide, lipopolysaccharide and outer-membrane proteins. Microbiology 142, 551-560.

Facius, D., Fartmann, B., Huber, J., Nikoleit, K., Schondelmaier, J. \& Steinhauser, S. (1999). Sequencing Brochure. Instructions for DNA Template Preparation, Primer Design And Sequencing with the LI-COR DNA Sequencer 4000 and 4200 series, Version 4. Ebersberg: MWG-BIOTECH AG.

Farfán, M., Miñana, D., Fusté, M. C. \& Lorén, J. G. (2000). Genetic relationships between clinical and environmental Vibrio cholerae isolates based on multilocus enzyme electrophoresis. Microbiology 146, 2613-2626.

Fox, G. E., Wisotzkey, J. D. \& Jurtshuk, P., Jr (1992). How close is close: $16 \mathrm{~S}$ rRNA sequence identity may not be sufficient to guarantee species identity. Int J Syst Bacteriol 42, 166-170.

Giraffa, G., Gatti, M., Rossetti, L., Senini, L. \& Neviani, E. (2000). Molecular diversity within Lactobacillus helveticus as revealed by genotypic characterization. Appl Environ Microbiol 66, 1259-1265.

Goodacre, R., Timmins, E. M., Burton, R., Kaderbhai, N., Woodward, A. M., Kell, D. B. \& Rooney, P. J. (1998). Rapid identification of urinary tract infection bacteria using hyperspectral whole-organism fingerprinting and artificial neural networks. Microbiology 144, 1157-1170.
Grecz, N. \& Dack, G. M. (1961). Taxonomically significant color reactions of Brevibacterium linens. J Bacteriol 82, 241-246.

Harrington, C. S. \& On, S. L. W. (1999). Extensive $16 \mathrm{~S}$ rRNA gene sequence diversity in Campylobacter byointestinalis strains: taxonomic and applied implications. Int J Syst Bacteriol 49, 1171-1175.

Helm, D., Labischinski, H. \& Naumann, D. (1991). Elaboration of a procedure for identification of bacteria using Fourier-Transform IR spectral libraries: a stepwise correlation approach. J Microbiol Methods 14, 127-142.

Holt, C., Hirst, D., Sutherland, A. \& MacDonald, F. (1995). Discrimination of species in the genus Listeria by Fourier transform infrared spectroscopy and canonical variate analysis. Appl Environ Microbiol 61, 377-378.

Irmscher, H.-M., Fischer, R., Beer, W. \& Seltmann, G. (1999). Characterization of nosocomial Serratia marcescens isolates: comparison of Fourier-transform infrared spectroscopy with pulsed-field gel electrophoresis of genomic DNA fragments and multilocus enzyme electrophoresis. Zentbl Bakteriol 289, 249-263.

Jones, D., Watkins, J. \& Erickson, S. K. (1973). Taxonomically significant colour changes in Brevibacterium linens probably associated with carotenoid-like pigment. J Gen Microbiol 77, 145-150.

Kämpfer, P. \& Kroppenstedt, R. M. (1996). Numerical analysis of fatty acid patterns of coryneform bacteria and related taxa. Can J Microbiol 42, 989-1005.

Kämpfer, P., Seiler, H. \& Dott, W. (1993). Numerical classification of coryneform bacteria and related taxa. J Gen Appl Microbiol 39, 135-214.

Kümmerle, M., Scherer, S. \& Seiler, H. (1998). Rapid and reliable identification of fermentative yeasts by Fourier-transform infrared spectroscopy. Appl Environ Microbiol 64, 2207-2214.

Lechner, S., Mayr, R., Francis, K. P., Prüß, B. M., Kaplan, T., Wießner-Gunkel, E., Stewart, G. S. A. B. \& Scherer, S. (1998). Bacillus weihenstephanensis sp. nov. is a new psychrotolerant species of the Bacillus cereus group. Int J Syst Bacteriol 48, 1373-1382.

Ludwig, W. \& Schleifer, K.-H. (1999). Phylogeny of Bacteria beyond the 16S rRNA standard. ASM News $\mathbf{6 5}, 752-757$.

Ludwig, W. \& Strunk, O. (1999). ARB, a software environment for sequence data. (http://www.biol.chemie.tu-muenchen.de/pub/ ARB/documentation/arb.ps).

Ludwig, W., Strunk, O., Klugbauer, S., Klugbauer, N., Weizenegger, M., Neumaier, J. \& Bachleitner, M. (1998). Bacterial phylogeny based on comparative sequence analysis. Electrophoresis 19, 554-568.

Maidak, B. L., Cole, J. R., Lilburn, T. G. \& 9 other authors (2000). The RDP (Ribosomal Database Project) continues. Nucleic Acids Res 28, 173-174.

Mallet, J. (2001). Concept of species. In Encyclopedia of Biodiversity, vol. 5, pp. 427-440. Edited by S. A. Levin. New York: Academic Press.

Mehta, A. \& Rosato, Y. B. (2001). Phylogenetic relationships of Xylella fastidiosa strains from different hosts, based on $16 \mathrm{~S}$ rDNA and 16S-23S intergenic spacer sequences. Int J Syst Evol Microbiol 51, 311-318.

Morton, A. C., Begg, A. P., Anderson, G. A., Takai, S., Lämmler, C. \& Browning, G. F. (2001). Epidemiology of Rhodococcus equi strains on thoroughbred horse farms. Appl Environ Microbiol 67, $2167-2175$. 
Naumann, D., Helm, D. \& Schultz, C. (1994). Characterization and identification of micro-organisms by FT-IR spectroscopy and FTIR microscopy. In Bacterial Diversity and Systematics, pp. 67-85. Edited by F. G. Priest and others. New York: Plenum.

Nübel, U., Engelen, B., Felske, A., Snaidr, J., Wieshuber, A., Amann, R. I., Ludwig, W. \& Backhaus, H. (1996). Sequence heterogeneities of genes encoding $16 \mathrm{~S}$ rRNAs in Paenibacillus polymyxa detected by temperature gradient gel electrophoresis. $J$ Bacteriol 178, 5636-5643.

Oberreuter, H., Seiler, H. \& Scherer, S. (2002). Identification of coryneform bacteria and related taxa by Fourier-transform infrared (FT-IR) spectroscopy. Int J Syst Evol Microbiol, 52, 91-100.

Owen, R. J., Ferrus, M. \& Gibson, J. (2001). Amplified fragment length polymorphism genotyping of metronidazole-resistant Helicobacter pylori infecting dyspeptics in England. Clin Microbiol Infect 7, 244-253.

Prieto, C. I., Aguilar, O. M. \& Yantorno, O. M. (1999). Analyses of lipopolysaccharides, outer membrane proteins and DNA fingerprints reveal intraspecies diversity in Moraxella bovis isolated in Argentina. Vet Microbiol 70, 213-223.

Ridell, J., Siitonen, A., Paulin, L., Lindroos, O., Korkeala, H. \& Albert, M. J. (1995). Characteriziation of Hafnia alvei by biochemical tests, random amplified polymorphic DNA PCR, and partial sequencing of $16 \mathrm{~S}$ rRNA gene. J Clin Microbiol 33, 2372-2376.

Rosselló-Mora, R. \& Amann, R. (2001). The species concept for prokaryotes. FEMS Microbiol Rev 25, 39-67.

Sander, A., Ruess, M., Bereswill, S., Schuppler, M. \& Steinbrueckner, B. (1998). Comparison of different DNA fingerprinting techniques for molecular typing of Bartonella henselae isolates. J Clin Microbiol 36, 2973-2981.

Saunders, K. E., McGovern, K. J. \& Fox, J. G. (1997). Use of pulsedfield gel electrophoresis to determine genomic diversity in strains of Helicobacter hepaticus from geographically distant locations. J Clin Microbiol 35, 2859-2863.

Seiler, H. (1983). Identification key for coryneform bacteria derived by numerical taxonomic studies. J Gen Microbiol 129, 1433-1471.

Seltmann, G., Voigt, W. \& Beer, W. (1994). Application of physico-chemical typing methods for the epidemiological analysis of Salmonella enteritidis strains of phage type 25/17. Epidemiol Infect 113, 411-424.

Seltmann, G., Beer, W., Claus, H. \& Seifert, H. (1995). Comparative classification of Acinetobacter baumannii strains using seven different typing methods. Zentbl Bakteriol 282, 372-383.

Skerman, V. B. D., McGowan, V. \& Sneath, P. H. A. (1980). Approved lists of bacterial names. Int J Syst Bacteriol 30, 225-420.

Stackebrandt, E. \& Goebel, B. M. (1994). A place for DNA-DNA reassociation and $16 \mathrm{~S}$ rRNA sequence analysis in the present species definition in bacteriology. Int J Syst Bacteriol 44, 846-849.

Stackebrandt, E., Rainey, F. A. \& Ward-Rainey, N. L. (1997). Proposal for a new hierarchic classification system, Actinobacteria classis nov. Int J Syst Bacteriol 47, 479-491.

Stan-Lotter, H., McGenity, T. J., Legat, A., Denner, E. B. M., Glaser, K., Stetter, K. O. \& Wanner, G. (1999). Very similar strains of Halococcus salifodinae are found in geographically separated Permo-Triassic salt deposits. Microbiology 145, 3565-3574.

Szállás, E., Koch, C., Fodor, A., Burghardt, J., Buss, O., Szentirmai, A., Nealson, K. H. \& Stackebrandt, E. (1997). Phylogenetic evidence for the taxonomic heterogeneity of Photorhabdus luminescens. Int J Syst Bacteriol 47, 402-407.

Taylor, D. E., Eaton, M., Chang, N. \& Salama, S. M. (1992). Construction of a Helicobacter pylori genome map and demonstration of diversity at the genome level. J Bacteriol 174, 6800-6806.

Tindall, B. J., Brambilla, E., Steffen, M., Neumann, R., Pukall, R., Kroppenstedt, R. M. \& Stackebrandt, E. (2000). Cultivatable microbial diversity: gnawing at the Gordian knot. Environ Microbiol 2, 310-318.

von Stetten, F., Francis, K. P., Lechner, S., Neuhaus, K. \& Scherer, S. (1998). Rapid discrimination of psychrotolerant and mesophilic strains of the Bacillus cereus group by PCR targeting of $16 \mathrm{~S}$ rDNA. J Microbiol Methods 34, 99-106.

Zavaleta, A. I., Martínez-Murcia, A. J. \& Rodríguez-Valera, F. (1997). Intraspecific genetic diversity of Oenococcus oeni as derived from DNA fingerprinting and sequence analyses. Appl Environ Microbiol 63, 1261-1267.

Received 24 October 2001; accepted 14 January 2002. 